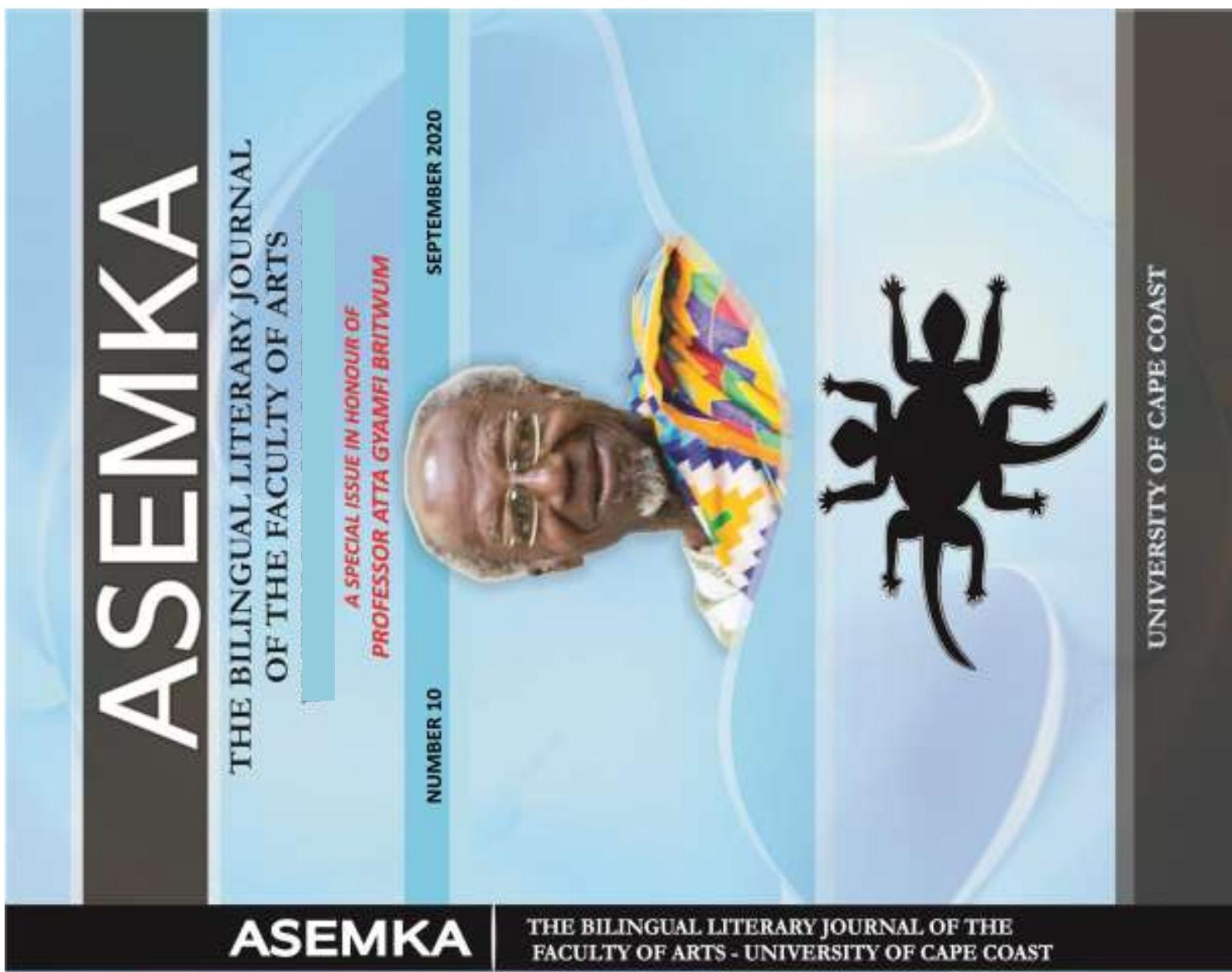





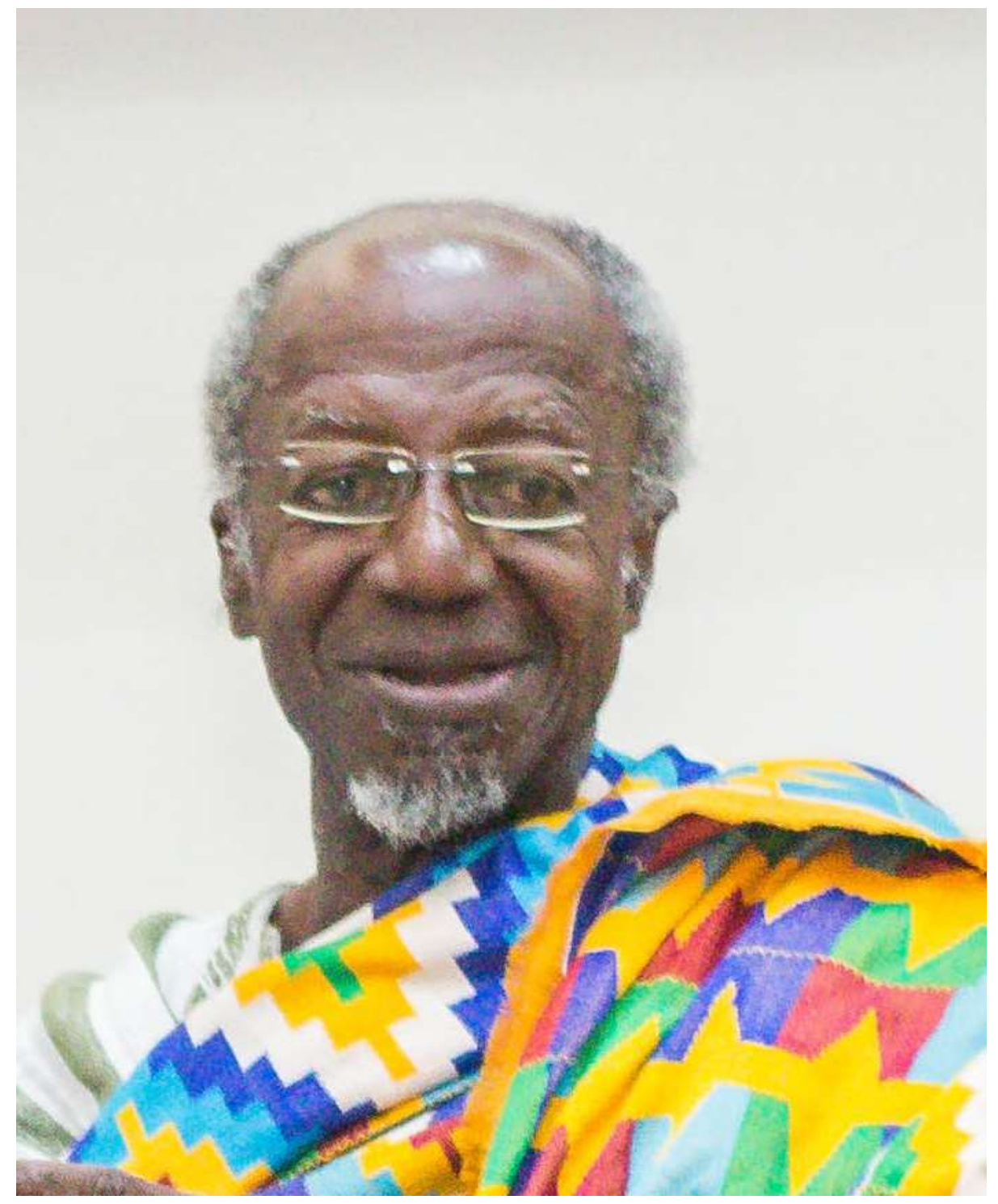

PROFESSOR ATTA GYAMFI BRITWUM 


\section{THE BILINGUAL LITERARY JOURNAL OF THE FACULTY OF ARTS UNIVERSITY OF CAPE COAST}

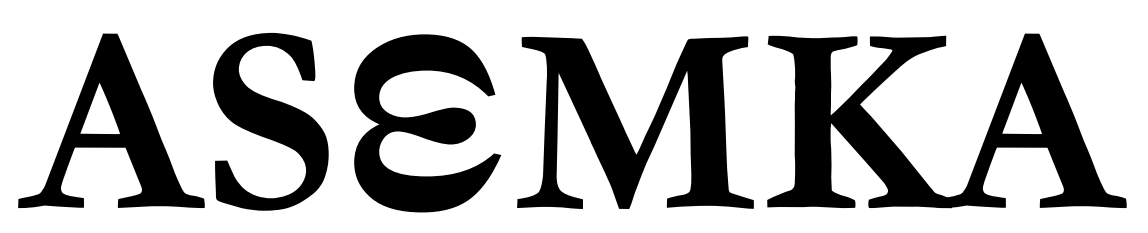

NUMBER 10

SEPTEMBER 2020

\section{EDITORIAL COMMITTEE}

Editor-in-Chief: Prof. Samuel Awuah-Nyamekye (Ph.D.)

Editor: $\quad$ Prof. Mawuloe Koffi Kodah (Ph.D.)

Associate Editors: Dr. Samuel Kwesi Nkansah

Dr. Mrs. Theresa Addai Munumkum

Dr. Isaac Mwinlaaru

Business Editor: Rev. Sr. Dr. Matilda Alice Nsiah

\section{EDITORIAL STAFF}

Mr. Stephen Owusu-Amoh

Mr. Isaac Kweku Grantson

\section{EDITORIAL ADVISORS}

Prof. Kwadwo Opoku-Agyemang, University of Cape Coast.

Prof. Joseph B. A. Afful, University of Cape Coast.

Prof. Raymond N. Osei, University of Cape Coast.

Prof. Richard V. Cudjoe, University of Cape Coast.

Prof. Victor K Yankah, University of Cape Coast.

Dr. Mousa Traore, University of Cape Coast. 


\section{ACKNOWLEDGEMENTS}

We acknowledge the contribution of the underlisted members of the Department of French who did preliminary editorial work on the papers:

Dr. Anthony Y.M. De-Souza (Chairman)

Prof. Raymond N. Osei

Prof. Mawuloe K. Kodah

Dr. Sylvester P. Krakue

Mr. Ofosu Addo-Danquah

Mr. Micheal Donkoh (Secretary)

\section{SUBSCRIPTION}

Assmka is published twice in the Academic year by the Faculty of Arts, University of Cape Coast. The annual out-of-Ghana subscription rate, including air-postage, is US\$29 for individuals, and US\$ 59 for institutions and libraries. Single issue rate for individuals is US\$18. Claims for copies not received must be made within three (3) months following an issue's publication. Correspondence should be addressed to:

The Editor, Assmka

Department of French

Faculty of Arts

College of Humanities and Legal Studies

University of Cape Coast

Cape Coast

Ghana, West Africa

Email: asemkajournal@ucc.edu.gh

\section{ADVERTISING}

Advertising rate, size specifications and related information are available upon request. Please, contact the General Editor for more information.

\section{SUBMISSIONS}

Assmka is an internationally-refereed journal of the Humanities. It publishes scholarly and imaginative articles in Literature, Language, and Culture generally, including, Orature, Film, Theatre, Music and Art. Essays, Interviews, Book Reviews, Poetry, Short Prose Fiction and Drama are welcome. Submitted manuscripts, in English and French, must be prepared in accordance with the most recent of APA or MLA style manual, where applicable. The author's identity and address may appear only on the cover- 
page and nowhere else within the submitted manuscript. All manuscripts should be submitted electronically through:

asemkajournal@ucc.edu.gh

Manuscript will be duly acknowledged within two (2) months of receiving them. Individuals whose works are accepted for publication may provide Assmka with a brief bio-data. The Editors cannot be held liable for lost or damaged manuscripts. Material published by Assmka does not necessarily represent the views of the Journal's Editors, Staff, Financial Supporters or the University of Cape Coast and its affiliates. These parties disavow any legal responsibility related to all submitted material.

\section{BACK ISSUES}

Back issues of Ascmka that are in stock may be ordered from the Editor at US\$20 per copy.

\section{GRANT SUPPORT}

Assmka is funded through grants from the Office of the Dean, Faculty of Arts; the Publications' Board; and the Office of the Vice-Chancellor, University of Cape Coast, Cape Coast, Ghana.

No part of this Journal may be reproduced, stored in a retrieval system, or transmitted in any manner whatsoever without express permission from the Editors, except in the case of brief quotations embodied in critical Articles and Reviews.

Copyright (C2020 by The Editors and The Faculty of Arts, University of Cape Coast. The cover and page design elements were inspired by the Adinkra symbols of Ghana. 


\section{DEDICATION \\ PROFESSOR ATTA GYAMFI BRITWUM}

Professor Britwum is a man of many parts. He is as much at home with Marxist Economic Theory and Feminist Sociological Thoughts, as he is with French and Francophone Literatures. He is a great teacher and Administrator of international acclaim. The Editors dedicate this special issue of Assmka to his honour. 


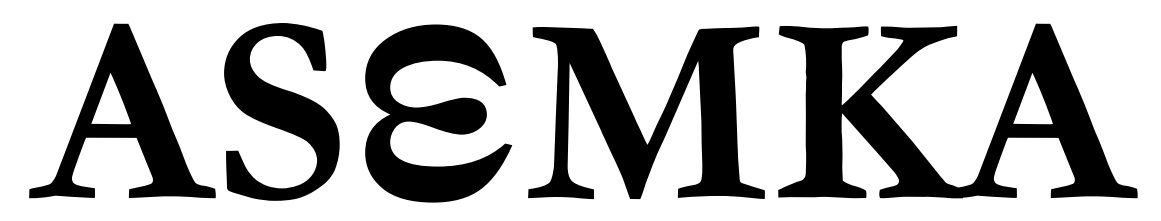

NUMBER 10

SEPTEMBER 2020 


\section{CONTENTS}

$\begin{array}{llll}\text { Editorial Committee } & \sim & \sim & \sim i i \\ \text { Editorial Staff } & \sim & \sim & \sim i i \\ \text { Editorial Advisors } & \sim & \sim & \sim i i \\ \text { Acknowledgements } & \sim & \sim & \sim i i i \\ \text { Subscription } & \sim & \sim & \sim i i i \\ \text { Advertising } & \sim & \sim & \sim i i i \\ \text { Submissions } & \sim & \sim & \sim i i i \\ \text { Back Issues } & \sim & \sim & \sim i v \\ \text { Grant Support } & \sim & \sim & \sim i v \\ \text { Dedication } \sim & \sim & \sim & \sim \\ \text { Foreword } \sim & \sim & \sim & \sim x \\ \text { Assmka: Editorial } & \sim & \sim & x i-x v i i\end{array}$

Articles

First Section - French

Britwum, A. G.

Insuffisances Théoriques Des Damnés De La Terre De

Frantz Fanon

$\sim$

$\sim 2-15$

Kodah, M. K.

Disculpation de Dieu dans le malheur des hommes:

Une lecture critique de Gouverneurs de la rosée de

Jacques Roumain $\sim \sim \sim 16-31$

Addo-Danquah, $O$.

Le récit de pensées: Une analyse comparative de Vol de nuit d'Antoine de Saint-Exupéry et La Condition humaine d'André Malraux

Kodah, M. K. \& Togoh, A. A. X.

Réactions des femmes face au conflit de genre dans C'est le soleil qui m'a brûlée et Tu t'appelleras Tanga de Calixthe Beyala

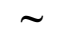

$\sim$

$\sim \quad 45-59$ 
Kudi, M. D.

La Littérature francophone face aux médias de télécommunication : Une nouvelle dynamique de la création romanesque, le cas de L'Énigme de retour et Tout bouge autour de moi de Dany Laferrière $\sim \quad$ 60-72

Gli, $M$.

Les faces du bonheur dans Vol de nuit d'Antoine de Saint-Exupéry $\sim \sim 73-85$

Krakue, S. P.

Christ haïtien : Gouverneurs de la rosée et La Bible $\sim 86-93$

Afari, E. S. K. \& Yegblemenawo, C. A. A.

Apports de la télésérie à l'amélioration de la compétence d'expression orale du FLE à l'école normale $\sim 94-116$

Bationo, J.-Cl.

Didactique de la littérature et littérature didactique:

l'exemple de la littérature africaine francophone en classe de langues étrangères au Burkina Faso

Second Section - English

Krakue, S. P.

Quod erat demonstrandum: A comparative study of narrative technique in Ama Ata Aidoo's Changes and Albert Camus'

Les justes (The Just Ones) 〜 $\sim$ $133-141$

Adjandeh, E. A.

Analysis of Wole Soyinka's Trials of Brother Jero in Relation to Ghanaian Religious Discourse $\sim 143-153$

Sam, C. A.

Decolonizing the Postcolony: Of Men, Spatial Politics and the New Nation in WA Thiongo's Wizard of the Crow.

Kambou, M. K. \& Traore, S. A.

Manipulation and the popular uprising in Burkina Faso in 2014. $\sim \quad \sim 172-189$ 
De-Soura, A. Y.M.

Test-taking Strategies of University of Cape Coast Students of

French as a Foreign Language: a Case Study $\sim 191-216$

Kambou, M. K. \& Soma, L.

Local Culture and EFL Vocabulary Learning $\sim \quad 217-238$

Kabore, A. \& Nazortin, C.

Critical Analysis of the Place and Importance of Literature in the Teaching / Learning of English and in School Leaving Certificate Examination in Burkina Faso from 1985 to 2018

Malgoubri, I., Sawadogo, M. \& Kambou, M. K.

Digital Audio-visuals Aids and Listening in English as a

Foreign Language Classrooms

Osei, R. N. \& Inusah, $H$.

A Critique of the Images of Heaven in the Scriptures of the

Abrahamic Religions: An Existentialist Perspective $\sim$ 270- 282

Negedu, A. K.

Lexical Gaps and Ideological Shift in the Translation of

Chinua Achebe's Things Fall Apart as "Le Monde

S'effondre" in French $\sim \sim 283-297$

Talburt, $T$.

Political Transformation and Development in Africa:

Lessons from Achebe's Things Fall Apart

$\sim 298-313$ 


\section{FORWORD}

All the papers in this Volume were presented at a three-day Conference in honour of Professor Atta Gyamfi Britwum who turns eighty years in March 2021. Most of those years he spent at University of Cape Coast, having cut his teeth as a young lecturer in French language and Literature-in-French in 1974. After many years of an illustrious career in teaching, publication and extension, he bowed out at age seventy, but he didn't get the well-deserved rest he was entitled to; he continues to support his Department and the University as a whole. Today, Professor Britwum's name is associated with high standards of professionalism which earned him the nickname 'L'oracle'. Indeed, it is impossible to find another name universally acknowledged as embodying the excellence in French education offered at the Department of French, University of Cape Coast.

The decision to honour Professor Britwum couldn't have been taken at a more appropriate time. It was planned to coincide with the fiftieth anniversary of the publication of the Beautyful ones are not yet Born, Ayi Kwei Armah's first novel. Britwum never grew tired of reading, teaching and examining it. Such was his respect for Armah's craft. So, the three-day Conference was as much a celebration of Armah's contribution to the shaping of the African novel as it was a tribute to Professor Britwum's work as a teacher of literature of immense influence.

One only has to look at the titles of the papers published in this Volume to get an idea of how deep his influence runs at UCC and beyond. Most of the contributors once upon a time sat at the master's feet, but are now scholars in their own right keeping the flame of French scholarship burning bright (George Cooper: "Polished in a high degree, as each froggie ought to be/Now they sit on other logs, teaching other little frogs.") A good number of the papers are on Literature, nonetheless not limited to Armah's works. No Surprise there. Nevertheless, there are Language papers there too. No surprise here either, for the man to whose honour the Volume is dedicated is equally at home in both Language and Literature

\section{Lawrence $K$. Owusu-Ansah,}

Department of English, UCC.

A Disciple 


\section{$A S E M K A:$ EDITORIAL}

This Special Edition of $A S E M K A$, a bilingual literary journal of the University of Cape Coast, is published in honour of Prof. Atta Gyamfi Britwum, a revered Associate Professor of Francophone African Literature and Civilisation in the Department of French, U.C.C. It contains twenty (20) papers centred on diverse areas of teaching and research in the Humanities and on the theme of the Conference - Literature and the Humanities in the 21 Century: Interdisciplinary Perspectives - held in his honour by the Department of French, University of Cape Coast, Ghana, $13^{\text {th }}-15^{\text {th }}$ Mars, 2019. To reflect Prof. Britwum's area of research interest, the essays are arranged in two sections according to his dominant medium of instruction (French language) and speciality (Literature and Civilisation), followed by those in English language. The first section consists of a set of nine (9) essays in French spanning between themes in Literature and Language. The second section is made up of a set of eleven (11) essays in English which examine issues in literary studies, Language and Didactics, ICT and French Education, Philosophy, and Translation, among others. This special arrangement is however representative of the bilingual nature of the Journal.

\section{First Section}

Britwum, A. G.'s paper titled, “Insuffisances Théoriques Des Damnés De La Terre De Frantz Fanon", presents the Fanonian perspective as a complement to the African nationalism that informed anticolonial struggles. The study posits that African nationalism, populist in nature, for failing to target the capitalist economic base, which defines colonialism, ended up strengthening it. It concludes that Fanon's anticolonialist perspective, despite its overt radicalism, is not designed to allow a "bottom-to-top change" in colonial / capitalist society.

Kodah, M. K.'s paper titled, "Disculpation de Dieu dans le malheur des hommes: Une lecture critique de Gouverneurs de la rosée de Jacques Roumain", puts into question the responsibility of God in the suffering of men on earth and the capacity of man to make and unmake himself. The study aims at absolving God of the guilt of the miseries of men, and also questioning the atheistic or anti-religion denunciation of this narrative 
text since its publication. The study is accomplished through a critical reading and a thoughtful analysis of Jacques Roumain's Gouverneurs de la rosée within the analytical structure of literary studies and sociocriticism.

Addo-Danquah, O.'s paper, "Le récit de pensées : Une analyse comparative de Vol de nuit d'Antoine de Saint-Exupéry et La Condition humaine d'André Malraux", drawing inspirations from theorists such as Léon Edel (1961) and later Dorrit Cohn (1981), examines what Antoine de Saint-Exupéry's Vol de nuit by and André Malraux's La Condition bumaine respectively can offer on the side of representations of the interior life. The study is posited within the framework of narratological theories.

Kodah, M. K. \& Togoh Tchimavor, A. A. in "Réactions des femmes face au conflit de genre dans C'est le soleil qui m'a brûlée et Tu t'appelleras Tanga de Calixthe Beyala" examine the reactions of women to gender conflict in Calixthe Beyala's C'est le soleil qui m'a brulée and Tu t'appelleras Tanga. The study critically reflects on the various ways women in Beyala's C'est le soleil qui m'a brulée and Tu t'appelleras Tanga react to oppression and exploitation resulting from patriarchal domination. It therefore examines the sources and nature of this conflict, and how women react to it in the two novels. The study points to the fact that, much as conflict emanating from patriarchal oppression and male's domination in human societies is inimical to the rights of women, the methods used by the latter to free themselves from this state of being remain questionable, in that, these methods defy rational thinking and are also a kind of reversal oppression and domination which are equally unacceptable.

Kudi, M. D.’s paper, “La Littérature francophone face aux médias de télécommunication: Une nouvelle dynamique de la création romanesque, le cas de L'Énigme de retour et Tout bouge autour de moi de Dany Laferrière", seeks to examine how pertinent painting, photography, television, telephone etc. are to the production of the contemporary Francophone novel. The study focuses on L'Énigme de retour (2009) and Tout bouge autour de moi (2011). The analysis is based on the perspective of literary intermediality propounded by Jürgen E. Muller which is characterised by an interaction between telecommunication media and literary text. The study establishes through these selected novels that these media forms are not simply another form of expression in the novel but rather a lens through which the story is narrated. 
Gli, M.'s paper titled, "Les faces du bonheur dans Vol de nuit d'Antoine de Saint-Exupéry", analyses the faces of happiness in Antoine de Saint-Exupéry's Vol de Nuit. The study is conducted through thematic approach. This approach is complemented by Maslow's theory of human needs. The collection of data or the collection of information is purely documentary. The study therefore seeks to establish a link between individual happiness and collective happiness in Saint-Exupéry's selected narrative text.

Krakue, S. P.'s paper, “Christ haïtien : Gouverneurs de la rosée et La Bible", attempts to question Jacques Roumain's Gouverneurs de la rosée in order to elucidate the novelist's use of the biblical text in his creative activity. The study demonstrates that Jacques Roumain's narrative text turns out to borrow biblical ideas not only to develop his plot but also to design his main character.

Afari, E. S. K. \& Yegblemenawo, C. A. A. in “Apports de la télésérie à l'amélioration de la compétence d'expression orale du FLE à l'école normale." examine the impact examine the impact of the use of serial movies as teaching aid on oral expression of French language learners in Colleges of Education in Ghana with the aid of smartphones. The study discovers that the use of serial movies in teaching French boosts learners' performance in oral communication. It therefore recommends that serial movies could be used in teaching French language lessons in order to enhance the oral communication competencies among learners.

Bationo, J.-Cl.'s paper titled, "Didactique de la littérature et littérature didactique : l'exemple de la littérature africaine francophone en classe de langues étrangères au Burkina Faso", shows not only how to teach literature in language class but also how to use didactic literature to develop social skills among learners to reduce vandalism, school violence, negative stereotypes, misunderstandings of intercultural nature while cultivating social peace and living together in a context of internationalization, globalization and digital revolution. The paper focuses on francophone African Literature and posits that methodological approach used for the didactic transpositions of literary content is based on the new orientation and the redefinition of the objectives of language teaching and on the didactic models of the aesthetic reception of didactics of literature which requires putting the learner in intensive interaction with the text and motivating $\mathrm{him} /$ her to express himself/herself on his/her reading experiences. 


\section{SECOND SECTION - ENGLISH}

Krakue, S. P.'s paper titled, “Quod erat demonstrandum: A comparative study of narrative technique in Ama Ata Aidoo's Changes and Albert Camus' Les justes (The Just Ones)", demonstrates through textual analysis, how in Ama Ata Aidoo's Changes and Albert Camus Les justes, the authors resort to a specific form of irony to bring the discussion of issues raised to a conclusion. The technique consists in demonstrating clearly a huge discrepancy between a "fine" idea and its practical usefulness. Both authors successfully use narrative technique. Albert Camus demonstrates the hollowness of the idea of fighting for justice through revolutionary violence and Ama Ata Aidoo similarly demonstrates the fatuousness of the theory of women-emancipation-through-polygamy.

Adjandeh, E. A. analyses selected reports in Ghanaian media in relation to the clergy and identifies how Wole Soyinka's theme is reflected in these media in her paper titled, "Analysis of Wole Soyinka's Trials of Brother Jero in Relation to Ghanaian Religious Discourse". The study seeks to examine the extent to which themes in Soyinka's Trials of brother Jero play out in religious discourses in Ghana. The global nature of the issues problematized by Wole Soyinka also comes out through this study as the work set in Nigeria is analyzed in relation to the selected articles set in Ghana. The paper relies on a content analysis of Trials of Brother Jero and similar themes presented in the selected articles, and makes a few recommendations on how these religious issues could be partially, if not wholly, resolved in Ghana.

Sam, C. A.'s paper, "Decolonizing the Postcolony: Of Men, Spatial Politics and the New Nation in WA Thiongo's Wizard of the Crow", examines how Ngugi Wa Thiongo's Wizard of the Crow blatantly explores Africa's complicity in a seemingly cyclic colonization in the $21^{\text {st }}$ century and its attendant consequences for the total liberation of Postcolonial Africa. The study examines the correlation between masculine representations, spatial reorganization and futurity as alternative ways in thinking about Africa's future through Bakhtin's theory of the carnival and other such concepts as polyphony and the grotesque. The result of the analysis is that the correlation between forms of communities and forms of masculinities is an indication of a vision of hope for Postcolonial Africa. 
Kambou, M. K. \& Traore, S. A. in "Manipulation and the popular uprising in Burkina Faso in 2014", analyse the different discourses in the build-up to the popular uprising in Burkina Faso on the $30^{\text {th }}$ and $31^{\text {st }}$ October 2014. It attempts to clarify how political and civil society leaders use language and other non-linguistic elements to influence the ordinary citizens' minds and, indirectly, their actions. The analysis is premised on Van Dijk's (2006) Sociocognitive approach. The paper analyses the cognitive, the social and the discursive dimensions of manipulation in six political speeches (two speeches from Civil Society, two from the ruling party and two from the political opposition). The results suggest that the three groups manipulated their audiences, and finally, the ruling party lost following the resignation of the then Head of State, making way for a Transition government to take over the reins of governance.

De-Souza, A. Y. M.'s paper “'Test-taking Strategies of University of Cape Coast Students of French as a Foreign Language: a Case Study.” seeks to provide a description of test-taking strategies that may inform teaching and learning of French for better output in tests against the background that Ghanaian students of French as a foreign language deploy strategies that are not adequate enough in answering test items in French. The study examines data gathered right after a French test by level 200 students, using recollective verbalization protocols.

Kambou, M. K. \& Soma, L. examine in their paper titled, "Local Culture and EFL Vocabulary Learning”, the influence of learners' culture on foreign language vocabulary. The paper seeks to demonstrate that there is a link between culture and lexico-semantic errors committed by learners of English as a foreign language among Dioula speaking students in Burkina Faso. A language test composed of two written activities was used as the data collection instrument. The results revealed that the Dioula speakers' English is influenced by their culture. These results have some pedagogical implications. They, therefore, suggest that we adapt the teaching of EFL vocabulary to learners' culture.

Kabore, A. \& Nazortin, C. in "Critical Analysis of the Place and Importance of Literature in the Teaching / Learning of English and in School Leaving Certificate Examination in Burkina Faso from 1985 to 2018", analyse the types of texts given at the "Baccalaureate A" written examination in the last thirty years. In this study, quantitative and qualitative 
data are collected. Baccalaureate written English papers are the main focus of our collection. Teachers and supervisors are interviewed. The study is grounded on "Reader-Response Theory" which stresses the interactions between the reader and the text. The results of the study show that the great majority of texts proposed for "Baccalaureate A" examination, in the last thirty years, are non-literary texts.

Malgoubri, I., Sawadogo, M. \& Kambou, M. K.’s paper titled, “Digital Audio-visuals Aids and Listening in English as a Foreign Language Classrooms", is an experimental study which investigates the potential of digital audio-visuals to improve the listening skills of EFL learners in secondary schools in Burkina Faso. On the assumption that learners born around the year 2000 are digital natives, the researchers try integrating smartphone-friendly audio-visuals in their EFL classrooms in a four-week experiment involving one Experimental Group and one Control Group. The experiment aims at gauging the effectiveness of those aids operated via students' smartphones in improving learners' listening and speaking skills. Independent T-tests were used to compare the groups and Sample Paired TTests to make comparisons within groups. The study suggests that, if appropriately used, smartphones are excellent devices for language teachers and learners in this digitizing world.

Osei, R. N. \& Inusah, H.'s paper, “A Critique of the Images of Heaven in the Scriptures of the Abrahamic Religions: An Existentialist Perspective." Critically examines the scriptural images of heaven as captured in the Abrahamic religions - Judaism, Christianity and Islam - from the existentialist perspective. The paper argues that the idea of life beyond this earthly existence for all human beings in a specially prepared location by God for eternal happiness for those who obey His commands on earth called Heaven, as propounded by the Abrahamic Religions, throws up a lot of problems, especially from the existentialist perspective. The study concludes that the scriptures' constructs of heaven appear self-contradictory and fail to strike a chord with the contemporary image of the ideal society when perused from the existentialist perspective and should, therefore, be discarded.

Negedu, A. K.'s paper "Lexical Gaps and Ideological Shift in the Translation of Chinua Achebe's Things Fall Apart as "Le Monde S'effondre" in French." examines the ideological divergence between the title of the original text and the title of the translation, following an observation 
that in translating Chinua Achebe's Things Fall Apart, Michel Ligny translates directly Igbo terminologies, realities and beliefs into the French language. The paper concludes that the ideology that the translated title projects to French-readers is totally different from the ideology that the original title projects to English-readers.

Talburt, T., in "Political Transformation and Development in Africa: Lessons from Achebe's Things Fall Apart", formulates critical perspectives on the significance of Achebe's novel for the socio-political and economic transformation and development of the African continent. The paper challenges one of the central assumptions in this story that Africa falls apart as soon as it comes in contact with Europe. It questions aspects of political conservatism exhibited in Okonkwo who is suspicious of fundamental changes to his society. The discussion is based on the jollof rice principle of political hybridisation of development which proposes the amalgamation of Westernised and non-Western ideas and systems, in order to achieve economic development, rather than totally rejecting Westernisation in its entirety. The study uses examples of Western-style democracy and State intervention in Africa to demonstrate the significance of embracing some aspects of Westernisation through political hybridisation. 




\title{
Insuffisances théoriques des Damnés de la terre de Frantz Fanon
}

\author{
Atta Gyamfi Britwum \\ University of Cape Coast, Cape Coast, Ghana.
}

\begin{abstract}
Résumé
Cette étude présente la perspective fanonienne comme un complément du nationalisme africain qui a informé les luttes anticoloniales. Le nationalisme africain, populiste, pour ne pas avoir ciblé la base économique capitaliste, qui définit le colonialisme, a fini par la renforcer. La perspective anticolonialiste de Fanon, malgré son radicalisme affiché, n'est pas faite pour permettre un « changement de fond en comble » de la société coloniale/capitaliste.
\end{abstract}

Mots-clés: décolonisation, violence, base économique, rapports de production.

\section{Rappel bio-bibliographique}

Nous rappelons quelques éléments bien connus de la biobibliographie de Frantz Fanon. Il est martiniquais, donc français de souche africainecaribéenne. Psychiatre de formation, il travaille à l'Hôpital Psychiatrique de Blida-Joinville en Algérie. Il renonce à sa nationalité française et rejoint le Front de Libération Nationale de l'Algérie en pleine lutte armée contre l'occupant français. Il est mort de leucémie à Washington à l'âge de 36 ans, ayant déjà à son actif de nombreux ouvrages conçus à partir de ses expériences de combattant de la liberté. À ce titre il participe non seulement à la lutte des nationalistes algériens, à partir de sa base tunisienne, mais aussi à des rencontres de réflexion qui réunissent des intellectuels nationalistes africains. Fanon se trouve représentant du gouvernement provisoire algérien au Ghana en 1960. Il se fait parrainer par les intellectuels français de gauche dont JeanPaul Sartre et Simone de Beauvoir. Deux de ses ouvrages ont retenu l'attention des spécialistes de littérature africaine et de science politique; mais aussi celle 
des tiers-mondistes ainsi que des radicaux de la gauche africaine et de la diaspora noire. Il s'agit de Peau noire, masques blancs (1952) et des Damnés de la terre (1961). Ce dernier ouvrage est l'objet de la présente étude.

\section{Les Damnés de da terre : structure/composition}

Les Damnés de la terre', préfacé par Jean-Paul Sartre, est une réflexion sur la décolonisation de l'Afrique. Nous remarquons qu'elle n'est pas basée sur des données collectées à dessein, mais sur les expériences personnelles de militant et d'intellectuel de l'auteur.

L'ouvrage porte une double cible : d'une part, il se propose comme une critique de la décolonisation telle qu'elle a été effectuée en Afrique noire ; et d'autre part il prescrit une stratégie pour la décolonisation vraie. Il se présente alors comme un constat et une prescription.

La charge émotive des Damnés de la terre est bien forte. La réflexion, surtout la phase saisie dans le premier chapitre intitulé « De la violence», est portée par un cri de colère. Certains critiques dont David Macey (2001), Megan Vaughan (2001) y perçoivent un problème personnel de Fanon. Mais il s'agit bien de la colère de militant; ce qui ne voile nullement les thèses de l'ouvrage que saisissent, dans tous les cas, ces critiques.

L'ouvrage sort en 1961, en une période où les indépendances africaines ont commencé à encaisser une certaine déconvenue chez les africains. Le mouvement communiste mondial connait un prestige certain et exerce une force d'attraction marquée à l'échelle mondiale surtout parmi la jeunesse et les militants se prétendant de gauche.

Le premier vers de l'Internationale, l'hymne de l'Association Internationale des Ouvriers, composée, on le sait, par le chansonnier français, Eugène Pottier, se dit «Debout, les damnés de la terre ». Fanon, se signalant déjà de la gauche internationale, tire le titre ${ }^{i}$ de son ouvrage de ce vers. Ce titre mène à croire que Fanon dans l'ouvrage cherche à ranger sa réflexion sur les indépendances africaines dans la lutte du prolétariat mondial d'obédience marxiste. C'est croire que Fanon est marxiste ou, à tous les moins, comme le font de nombreux critiques dont David Caute (1970) et Emmanuel Hansen (1978), qu'il est socialiste. La présente étude affirme que Fanon n'est ni l'un ni l'autre. 


\section{Les thèses des Damnés de la terre}

\section{La trahison de la bourgeoisie nationale}

La thèse centrale des Damnés de la terre est que les indépendances africaines ont été un trompe-l'œil parce que la dose de violence qui y a été investie était maigre ou inexistante. Elles ont été, pour la plupart, livrées par des discussions à l'amiable autour des conférences de table ronde. Or, le colonialisme s'est imposé et s'est maintenu par la violence meurtrière. Tout processus visant à le démanteler doit obligatoirement recourir à la même violence meurtrière. La décolonisation vraie est un changement de fond en comble. Elle est le remplacement d'une espèce humaine par une autre espèce humaine. Elle permet aux derniers du régime colonial, les colonisés, de devenir les premiers. La situation coloniale recèle deux forces congénitalement opposées obéissant à une logique «d'exclusion réciproque », animées par les colons et les colonisés. La décolonisation élimine purement et simplement l'un des termes du conflit, permettant d'unifier l'espace colonial compartimenté. Ce terme est le colon. Conçu dans cette perspective, la décolonisation vraie, ne peut être effectuée sans faire couler du sang de part et d'autre. C'est dire qu'il est bien facile de déterminer si la décolonisation a eu lieu. C'est que le changement de fond en comble saute aux yeux - au sens propre. Lorsque le premier Président de la République gabonaise nouvellement indépendante déclare, «Le Gabon est indépendant, mais entre le Gabon et la France rien n'est changé, tout continue comme avant» ( (p. 46), il avoue en effet que la décolonisation n'a pas eu lieu au Gabon. De même le texte cite les patriotes sénégalais qui, réclamant l'africanisation des cadres, constatent que Senghor africanise les cadres européens qui occupent les postes, pour montrer que le premier indice de la décolonisation n'est pas acquis : le remplacement d'une espèce humaine, les colons, par une autre espèce humaine, les colonisés. L'indépendance du Sénégal comme celle du Gabon, à titre d'exemple, n'ont pas donné alors la vraie décolonisation.

C'est dire en clair que l'indépendance s'arrache dans le sang; que les indépendances acquises sans la violence ne sont pas de vraies indépendances. Il en a été ainsi principalement à cause des intérêts de la classe qui dirige les mouvements nationalistes: la bourgeoisie nationale faite des «élites intellectuelles et commerciales» résidant essentiellement dans les zones urbaines. Les partis nationalistes issus de ces mouvements ont une clientèle strictement urbaine : "des ouvriers, des instituteurs, des artisans et des commerçants» (p. 42). Ces citadins, dans leur ensemble, profitent de la situation coloniale. Ils sont des «enfants gâtés » (p. 34) du colonialisme. Ils ne veulent pas ce changement de fond en comble qui définit la décolonisation, 
simplement parce qu'ils risquent de perdre les quelques avantages qu'ils tirent de la situation coloniale. L'effort de mobilisation des partis politiques nationalistes laisse de côté la paysannerie qui, elle, comme par nature, est portée vers un changement de fond en comble et à user de la violence pour l'effectuer. C'est que la paysannerie constitue les laissés-pour-compte de la situation coloniale. Elle est seule de toutes les catégories sociales de la colonie à n'avoir rien à perdre dans le démantèlement total du système colonial.

\section{vers la liberté coloniale}

C'est dire que la décolonisation de l'Afrique noire n'a pas eu lieu, qu'elle reste à faire. Et Les Damnés de la terre propose la bonne stratégie. Elle fait de la violence une arme incontournable. "L'homme colonisé se libère dans et par la violence » (p. 61). Emmanuel Hansen (1978) fait remarquer que «Quoique Fanon emploie le mot violence assez souvent dans ses œuvres, surtout dans Les Damnés de la terre, il ne le définit nulle part $»^{2}$. Bien au contraire, Fanon se donne la peine d'expliciter à maintes reprises ce qu'il entend par la violence. La décolonisation « laisse deviner, clame-t-il, des boulets rouges, des couteaux sanglants » (p. 26). Il s'agit ainsi de la violence physique dirigée, d'une part, contre le système colonial. Ce qui le fait préciser : "Détruire le monde colonial c'est ni plus ni moins abolir une zone, l'enfouir au plus profond du sol ou l'expulser du territoire»(p. 29). Il en nomme les moyens : «(...) le colonisé, sa mitraillette au poing, affronte enfin les seules forces qui lui contestent son être : celles du colonialisme » (p. 40). D'autre part, cette violence physique cible les colons : «C'est que le colon ne cesse jamais d'être l'ennemi, l'antagoniste, très précisément l'homme à abattre » (p. 35). Le texte ne laisse pas de doute sur la visée ultime de cette violence : «travailler c'est travailler à la mort du colon » (p. 61). La preuve définitive de la mort c'est la décomposition du cadavre: "Pour le colonisé, la vie ne peut surgir que du cadavre en décomposition du colon» (p. 65). Comme pour se démarquer d'un Senghor (1964) qui, dans 'Prière de paix', après avoir mis en exergue les crimes de l'occupant, plaide le pardon pour lui :

Seigneur Dieu, pardonne à l'Europe

blanche!

(...) Seigneur, parmi les nations

blanches, place la France à la droite du Père.

La stratégie de la bonne décolonisation distingue deux types de colonisés : d'un côté, des citadins faits des intellectuels, les cadres et la clientèle des partis nationalistes; et de l'autre, des paysans et des quelques intellectuels progressistes. Les citadins sont traîtres à la cause nationale pour des raisons déjà évoquées. Par contre, il existe dans la colonie quelques intellectuels 
progressistes acquis à la cause nationale. Ces intellectuels progressistes s'intégrant aux masses paysannes se re-forment à «l'école du peuple» (p. 93). L'école du peuple se définit en termes d'un contact prolongé avec la paysannerie dans des conditions de lutte armée. Ce contact prolongé permet aux intellectuels de se débarrasser de tous les acquis négatifs recueillis à l'école occidentale. La vision du monde révolutionnaire de la paysannerie se substitue aux acquis négatifs. Le mouvement issu de ce contact se renforce avec les enseignements positifs que les intellectuels progressistes auraient acquis à l'école occidentale. Il en résulte une lutte armée qui se déclenche. Cette lutte prend la campagne d'abord et s'achemine dans les villes en passant par des éléments lumpen prolétaires récemment arrivés de la campagne, donc libres de la corruption urbaine.

\section{vers la reconstruction nationale}

Les Damnés de la terre fait des propositions pour la reconstruction nationale au lendemain de l'indépendance. Les pays nouvellement débarrassés du joug colonial doivent avant tout refuser le choix entre le socialisme et le capitalisme. Il faudra plutôt inventer « des valeurs qui leur soient propres, des méthodes, un style qui leur soient spécifiques »(p. 70). Néanmoins, le texte prône sans trop de conviction un certain socialisme assorti d'un programme de nationalisation du « secteur tertiaire (...) de loin le plus important» de l'économie coloniale (p. 130). Il ne pose pas la problématique des rapports de propriété (mode d'appropriation des moyens de production) (Marx, 1975). Alignée sur ces «valeurs qui [sont] propres" aux pays nouvellement indépendants, est une politique culturelle qui s'enracine dans le peuple (sans distinction de classe) et qui obéit ainsi à la logique de la libération. «Se battre pour la culture nationale, c'est d'abord se battre pour la libération de la nation, matrice matérielle à partir de laquelle la culture devient possible» (p. 170). La culture nationale se fonde sur la lutte du peuple et s'aligne sur la lutte d'autres peuples. Le texte s'en prend au Président Senghor qui donne l'ordre à la délégation sénégalaise à l'Assemblée Générale des Nations Unies d'appuyer les thèses françaises sur une Algérie se bataillant contre l'occupant français. C'est là un indice d'une politique culturelle qui défend les intérêts non d'autres peuples en lutte mais plutôt ceux de l'oppresseur. Il s'agit là d'une politique culturelle mal décolonisée. 


\section{Les failles théoriques}

Cette section vise à montrer que Les Damnés de la terre fait preuve d'une certaine familiarité avec des thèses et concepts marxistes. Mais il applique mal ceux dont il use. Les bases théoriques de la réflexion s'en trouvent affaiblies.

\section{les classes sociales/la base économique}

Le cri de colère contre le Blanc, contre le colon qui marque le style des Damnés de la terre donne au nationalisme qu'il affiche des allures radicales. Le nationalisme est une vision du monde qui prend fait et cause pour le «nous » sans distinction de classe contre le "eux » ennemis également sans distinction de classe. Le radicalisme du texte se renforce par de nombreux recours à des thèses et concepts marxistes — mais employés pour la plupart à tort.

Ce que l'essai appelle «l'espèce dirigeante » dans la société coloniale se détermine non à la base des considérations économiques mais plutôt à la base des considérations raciales. L'emploi de l'« espèce »- que l'essai préfère au concept consacré de «classe »- donne au phénomène colonial qu'il cible une identité raciale non l'économique à laquelle «la classe » sociale renvoie. Et le texte de préciser: "On est riche parce que blanc. On est blanc parce que riche » (p. 28). Il y aura alors, affirme le texte, à réviser les thèses marxistes sur le concept de classe car «Ce ne sont ni les usines, ni les propriétés, ni le compte en banque qui caractérisent d'abord la 'classe dirigeante'. L'espèce dirigeante est d'abord celle qui vient d'ailleurs, celle qui ne ressemble pas aux autochtones, 'les autres'» (p. 28).

Mais l'appropriation privée des moyens de production, l'appropriation privée des usines, des banques et d'autres types de moyens de production servent justement à définir la classe dominante, en l'occurrence, la bourgeoisie. Une société de classe se distingue par l'appropriation privée des moyens de production. Elle se compose, d'un côté, de ceux qui possèdent l'essentiel de l'ensemble des moyens de production constituant la classe dominante, et, de l'autre, de ceux qui ne détiennent que leur force de travail constituant la classe dominée. L'injustice foncière de la société de classe se joue au niveau de cette base économique. Le fait que la classe dirigeante soit étrangère ou autochtone ne change rien à l'injustice foncière de la société de classe. Autrement dit la société de classe n'est pas moins injuste parce que sa classe dominante est une classe autochtone. Le fait que la classe dominante soit étrangère peut à la rigueur être un élément affectif rendant l'injustice plus intolérable aux autochtones qui, dans leur ensemble, se trouvent exclus de la classe dominante. Le mouvement nationaliste africain se focalise, comme le fait Fanon, sur l'étranger, sur «ses canons et ses machines", sur la discrimination raciale, 
l'indigénat, «les impôts les corvées les chicottes » et autres abus des droits de la personne, motifs récurrents de la littérature anti-coloniale (Maran, 1938; Senghor, 1964; Oyono, 1956; Béti, 1961). Les motifs se repèrent sous forme de faits historiques notamment dans L'Histoire de l'Afrique noire de Joseph KiZerbo (1973). Il s'agit là des abus relevant de la superstructure de la société coloniale. Ils ne définissent pas le colonialisme. Fanon s'enhardit dans le texte à proposer une révision des thèses marxistes, sans avoir acquis une connaissance suffisante du marxisme!

Cette insuffisance s'avère encore plus frappante dans l'emploi du concept de «bourgeoisie» qu'il applique à une catégorie sociale africaine/coloniale qu'il dénomme «la bourgeoisie nationale ». Il repère certains des groupes qui la composent comme «avocats, commerçants, propriétaires terriens, médecins, fonctionnaires supérieurs», «les cadres universitaires » (p. 110). Mais, précise le texte, cette bourgeoisie "est une bourgeoisie sous-développée ». «(...) Au sein de cette bourgeoisie nationale on ne trouve ni industriels, ni financiers » (p. 110). Autant dire qu'elle n'existe pas. Ce qui est le cas en effet. La bourgeoisie en tant que classe sociale se définit par rapport à l'appropriation privée des moyens de production se constituant en capital. On ne possède nuls moyens de production, on n'est pas bourgeois. Nous trouvons cet emploi abusif du concept de bourgeoisie dans l'essai d'Emmanuel Hansen (1978). Il dit du père de Fanon qu'il travaillait à la douane. Les informations qu'il fournit sur sa mère ne relèvent que du rôle genre reproductif où le patriarcat confine la femme. Pourtant il prétend que Fanon est d'une famille bourgeoise! Par ailleurs, il signale le mépris que Fanon éprouve pour les bourgeois noirs qu'il trouve à Paris. Hansen repère encore des bourgeois ghanéens que Fanon en poste à Accra va croiser. Il s'agit toujours d'une bourgeoisie qui, comme dans Les Damnés de la terre, ne se trouve pas une classe de possédants dans les rapports sociaux de production.

Le texte s'amène de cette manière à opposer les citadins aux paysans. Les citadins sont traîtres à la cause nationale parce qu'ils profitent du système colonial. Et on se retrouve avec cet abus de concept qui fait du 'prolétariat [...] la fraction «bourgeoise » du peuple colonisé' (p. 80) simplement à la base de la place supposée privilégiée qu'il occupe dans le système colonial. Mais au fait, on est bourgeois parce qu'on relève d'une classe sociale dite " la bourgeoisie », propriétaire privé des moyens de production capitalistes. On est prolétaire parce qu'on n'a que sa force de travail qu'on est obligé de vendre au bourgeois pour pouvoir subsister. Le profit du bourgeois est fait du surplus généré par le prolétaire que le bourgeois s'approprie sans récompense. Marx dénomme ce surplus la plus-value. L'appropriation sans récompense par le bourgeois de la plus-value générée par le travailleur est ce qui définit l'exploitation (Engels, Socialisme utopique et scientifique, 1975). Le prolétaire se fait exploiter ainsi par le 
bourgeois. On est prolétaire, on n'est pas choyé par celui qui vous exploite. Surtout on ne devient pas, même entre guillemets, bourgeois !

La perspective nationaliste vibrante qui abuse du concept de classe va faire de la paysannerie la seule classe révolutionnaire dans le contexte colonial. Le critère ne dérive pas de la place qu'elle occupe dans la production sociale mais de la considération tout subjective qu'elle est la seule classe qui n'ait rien à perdre dans le démantèlement du colonialisme. De ce fait, elle est portée, comme par défaut, à user de la violence pour réaliser la vraie décolonisation. Fanon fait de la paysannerie la seule classe révolutionnaire dans le contexte colonial, toujours sans poser la problématique des rapports de propriété.

\section{La superstructure}

La base économique de toute société dérive son identité de la configuration particulière des rapports de propriété. Sur cette base économique s'érige la superstructure (Marx, 1975). La superstructure est l'ensemble des idées, des systèmes de pensée et de leur application dans la culture, dans les institutions sociales dont le plus important est l'état. Dans une société de classe, la superstructure sert primairement les intérêts de ceux qui détiennent les moyens de production aux dépens de ceux qui n'ont que leur force de travail, tout en faisant croire qu'elle s'occupe équitablement de l'ensemble de la société. Le mode d'appropriation des moyens de production est alors l'élément crucial, distinguant les sociétés humaines (Marx, 1975). L'ensemble du mouvement nationaliste africain a ciblé les abus de la superstructure relevant pour la plupart de ce qui se dénomme de nos jours la gouvernance. Il a laissé intacte la base économique coloniale typifiée par l'appropriation privée des moyens de production. C'est là où le colonialisme dérive son identité. La classe dirigeante de la colonie est la bourgeoisie métropolitaine: la bourgeoisie française, britannique ou portugaise selon le cas. L'élément crucial ici n'est pas l'identité nationale ou raciale de cette classe ; mais bien plutôt sa place dans la production sociale. La fixation sur des considérations nationales ou raciales qui laisse intacte la base économique de la société coloniale — va permettre au colonialisme (c'est-à-dire le capitalisme) de survivre aux indépendances.

Par ailleurs le texte donne à la violence du colonisé des attributs qui ne se fondent pas dans les faits. Sa présence est un déterminant de la vraie décolonisation. Elle permet de transformer les colonisés, dit le texte, de «spectateurs écrasés d'inessentialité en acteurs privilégiés » (p. 26). Appliquée par le paysan elle se dirige vers «l'ennemi (...) à abattre» (p. 35), le colon. La fixation sur la violence, et, d'une manière générale, la vision du monde nationaliste, donnent une perception floue de la situation coloniale, frustrant par là-même l'élaboration d'une stratégie pour la combattre. Précise le texte : 
La violence qui a présidé à l'arrangement du monde colonial, qui a rythmé inlassablement la destruction des formes sociales indigènes, démoli sans restrictions les systèmes de références de l'économie, les modes d'apparence, d'habillement, sera revendiquée et assumée par le colonisé au moment où, décidant d'être l'histoire en actes, la masse colonisée s'engouffrera dans les villes interdites (p. 29).

Ce que le texte appelle «les systèmes de référence économique » correspond en effet au mode de production de la société pré-coloniale, majoritairement communaliste (Asamoa, 1986). Après la saisie de l'espace qui sera la colonie, le colonialisme engage un processus qui consiste à monter le mode de production capitaliste à la place du communaliste qu'il trouve et qu'il détruit. «Les formes sociales indigènes (...) les modes d'apparence, d'habillement », sont des éléments de la superstructure. Ils perdent leur support matériel, à savoir la base économique communaliste désormais en effritement. À leur place s'érigent d'autres formes alignées sur la nouvelle base économique capitaliste. Le texte, évidemment, est loin de songer au mode de production que «la masse, s'engouffrant dans les villes interdites», montera à la place du colonial/capitaliste qu'elle détruit. Au fait, l'action de la masse aura à attendre ce que le texte formule comme l'invention de «l'homme total que l'Europe a été incapable de faire triompher » (p. 236). Cet homme total, qu'il soit présent ou à venir, n'est qu'une formule vague qui flatte la sensibilité nationaliste mais ne mène à aucune construction sérieuse. En effet, Le texte se laisse prendre dans le subjectivisme propre au mode de réflexion idéaliste. En spéculant sur la formation sociale à monter au lendemain de la décolonisation réussie, il met en garde contre l'exemple des États-Unis d'Amérique.

Il y a deux siècles, une ancienne colonie européenne s'est mise en tête de rattraper l'Europe. Elle y a tellement réussi que les Etats-Unis d'Amérique sont devenus un monstre où les tares, les maladies et l'inhumanité de l'Europe ont atteint des dimensions épouvantables. (p. 236)

L'impérialisme américain est le produit des forces sociales objectives non des considérations subjectives mues par une volonté de rattraper qui que ce soit.

La décolonisation, nous dit le texte, se résume en « un panorama social changé de fond en comble» (p. 25). Il conçoit le monde colonial comme coupé en deux, fait de deux forces congénitalement antagonistes. Le processus 
de la décolonisation permet de résoudre cet antagonisme en éliminant simplement la partie colon des forces en présence. Il unifie ce monde divisé, précise le texte, "sur la base de la nation, quelquefois de la race » (p. 32). D'abord, on relève cette pulsion nationaliste qui, ici, se confond avec le racisme. Elle cible, non la formation socio-économique capitaliste qu'est la société coloniale, mais des individus, des personnes, des espèces «d'hommes [et de femmes]", l'habitant. Ensuite la perspective adoptée ignore la loi dialectique de la lutte et de l'unité des contraires. Cette loi veut que chaque entité soit faite des composantes à la fois conflictuelles et complémentaires. On n'élimine pas alors les contradictions inhérentes à la situation coloniale en supprimant l'une des forces en conflit.

Le texte repère une ligne de démarcation qui signale le partage en deux du monde colonisé. Il la caractérise comme étant surveillée par des forces armées. En régime colonial, "l'interlocuteur valable et institutionnel qui est aussi le porte-parole du colon et du régime d'oppression est le gendarme ou le soldat» (p. 27). Il recourt au concept marxiste de l'état pour illustrer la compartimentation du monde colonial. L'état, instrument de domination de classe, selon la conception matérialiste de l'histoire, use de deux outils pour assurer l'ordre qui sert primairement les intérêts de la classe régnante. Ces outils sont d'une part les instruments de coercition, les forces armées, qui imposent le respect de l'ordre par les moyens rudes; et de l'autre les institutions de socialisation qui assurent le respect de l'ordre par les moyens feutrés et de cette manière «allègent considérablement la tâche des forces de l'ordre » (p. 27). Ces outils sont à l'œuvre dans la société capitaliste, précise le texte. Dans les colonies, par contre, il n'existe que les forces de l'ordre. C'est ce qui fait dire au texte que dans les colonies «l'interlocuteur valable et institutionnel du colonisé est le gendarme ou le soldat (p. 27) ». Il y a encore ici un abus de concept. C'est qu'il est inconcevable que l'état s'appuie sur les seules forces armées pour assurer l'ordre. D'ailleurs des institutions de socialisation existaient bien dans les colonies. On y trouvait des écoles, la presse, les syndicats, des institutions religieuses... Ces institutions assuraient «l'enseignement, religieux ou laïque, la formation de reflexes moraux transmissibles de père en fils, l'honnêteté exemplaire d'ouvriers décorés après cinquante années de bons et loyaux services, l'amour encouragé de l'harmonie et de la sagesse » (p. 27) que le texte ne reconnait que dans la métropole.

La fonction que le texte attribue à l'église fait bien d'elle une institution de socialisation sans que l'auteur la perçoive ainsi : «L'Église aux colonies est une Église de Blancs, une église d'étrangers. Elle n'appelle pas l'homme colonisé dans la voie de Dieu mais bien dans la voie du Blanc, dans la voie du maitre, dans la voie de l'oppresseur » (p. 30). C'est dire que l'Église conditionne le colonisé à se soumettre à son oppresseur. C'est là en effet la 
fonction d'une institution de socialisation. Il existe alors au moins une institution de socialisation dans les colonies. Le texte en livre plutôt une perception raciale, pour ne pas dire raciste. L'Église relève de la superstructure. On ne peut apprécier sa valeur et fonction en régime colonial, comme ailleurs, que par rapport à la base économique. L'Église se colore d'une fonction spirituelle, mais dans le fond elle remplit une fonction tout physique, celle de renforcer et d'aider à perpétuer les intérêts, disons, bassement matériels de la classe des possédants de la colonie. Cette classe se trouve composée des Blancs pour la plupart. Mais c'est là un accident de l'histoire. Elle serait composée des Noirs, l'effet serait le même.

\section{Au-delà de la décolonisation}

Le texte reproche aux partis nationalistes de ne pas avoir de programme à mettre en place au lendemain de l'indépendance. Mais il n'en propose pas un non plus. Il ne propose que de remplacer une espèce humaine par une autre espèce humaine. Certains critiques y voient un programme socialiste. David Caute (1970) affirme que le socialisme court les pages des Damnés de la terre. Jean-Paul Sartre, dans sa préface, perçoit la visée socialiste de la révolution coloniale que prône Fanon. Emmanuel Hansen (1978) rapproche Fanon du socialisme avec un peu d'hésitation. Or, le texte met en garde contre le choix entre le capitalisme et le socialisme. «Les pays sous-développés (...) doivent s'efforcer de mettre à jour des valeurs qui leur soient propres, des méthodes, un style qui leur soient spécifiques» (p. 69). La définition de la décolonisation apparait dès le début de l'essai. Elle exhorte à démolir le monde colonial. Sekyi-Otu (1996) déploie un tour de force d'érudition et d'éclectisme théorique pour couler le long des pistes posées dans Les Damnés de la terre. Sekyi-Otu ne repère pas les errements théoriques qui livrent entre autres la fixation sur la race. Il ressort des Damnés de la terre un racisme qui ne dit pas son nom. Il ne permet pas, surtout, d'envisager ce qu'on monte à la place du colonialisme qu'il incite à démolir.

Le texte propose des prescriptions sur la culture nationale à façonner au lendemain de l'indépendance vraie. La culture, en tant que produit des activités mentales, relève, elle aussi, de la superstructure. Fanon fait abstraction totale du mode d'appropriation des moyens de production sur lequel s'appuiera la culture nationale dont il dessine les contours. Le texte cite en exemple un élément de la culture nationale qu'il faut. Il le trouve dans un poème du Guinéen Kéita Fodéba, "authentique invitation à la réflexion, à la démythification, au combat » ayant une "incontestable valeur pédagogique » (p. 165). Absente de cette appréciation est la base économique sur laquelle cette manifestation culturelle s'appuie et qui la détermine en dernière analyse. 
La Guinée du poème de Kéita Fodéba est encore prise dans les structures néocoloniales/capitalistes. Déterminer en quoi ce poème renforce ou combat cette base économique capitaliste, à partir d'un cadre de réflexion antithétique au capitaliste, permet de mieux juger de sa portée idéologique.

\section{Conclusion : pour la construction du socialisme}

Les Damnés de la terre fait de la décolonisation, qu'il définit comme le changement de fond en comble de la société coloniale/capitaliste, le point d'achoppement de son argument. Or le changement radical de la société capitaliste ne peut qu'entrainer la construction du socialisme contre lequel le texte met en garde. Fanon, dans ce texte, se révèle finalement un nationaliste africain classique. Néanmoins, force est de lui reconnaitre un certain radicalisme. Mais ce radicalisme se repère dans la forme, non dans le fond de son discours. Ce discours ne fait que tourner dans la superstructure de la société coloniale.

Il est temps de corriger le tir: Combattre le colonialisme et son succédané qu'est le néo-colonialisme, c'est combattre le capitalisme. C'est lui opposer son antithèse, le socialisme scientifique, élaboré par Karl Marx et son ami et collaborateur, Friedrich Engels.

\section{Notes}

1. Selon Alice Werki (2002), 'le titre fut le seul qu'il choisit lui-même et non ses éditeurs.'

2. 'Although Fanon employs the word violence quite often, in his works, especially in The Wretched of the Earth, he nowhere defines it' (The translation into French is mine).

\section{Références}

Aidoo, A. A. (1969). Anowa. London: Longman.

Armah, A. K. (1970). The Beautyful Ones Are Not Yet Born. London: Heinemann.

Armah, A. K. (1974). Why Are We So Blest? London: Heinemann.

Asamoa, A. ( 1986). The Ewe of South-Eastern Ghana and Togo on the Eve of Colonialism, A Contribution to the Marxist Debate on Pre-Capitalist SocioEconomic Formations. Accra: Ghana Publishing Company.

Béti, Mongo. (1976). Le Pauvre Christ de Bomba. Paris: Buchet et Chastel. 
Caute, D. (1972). Fanon. London: Fontana.

Cherki, A. (2OO2). Preface. Fanon, Frantz. Les Damnés de la terre. Paris: Editions Maspero poiche.

Diop, D. (1954). Coups de pilon. Paris: Présence africaine.

Engels, F. (1967). Origine de la famille, de la propriété privée et de l'etat. Moscou: Editions du Progrès.

Engels, F. (1975). "Socialisme utopique et scientifique." Engels, Marx \&. Oeuvres choisies. Moscou: Editions du progrés. 390-448.

Fanon, F. (1961). Les Damnés de la terre. Paris,: Maspero.

—. (1952). Peau noire, masques blancs. Paris: Éditions du Seuil.

Hansen, E. (1978). Frantz Fanon: Social and Political Thought. Nairobi, Ibadan, Lusaka: Oxford University Press.

Ki-Zerbo, J. (1973). Histoire de l'Afrique noire. Paris: Hatier.

Lénine, V. I. (1967). L'état et la révolution. Moscou: Éditions du Progrès.

Maran, R. (1938). Batouala. Paris: Albin Michel.

Marx, K. (1975). Préface à La Critique de l'économie politique. Marx, Karl and Friedrich Engels. CEurres choisies. Moscou: Éditions du Progrès.

Oyono, F. (1956). Une Vie de boy. Paris: Julliard.

Sekyi-Otu, A. (1996). Fanon's Dialectic of Experience. Cambridge, Massachusetts: Harvard University press.

Senghor, L. S. (1964). Poèmes. Paris: Édtions du Seuil.

Vaughan, M. (2001). in London Review of Books, Vol. 23 No 20, 18 October 2001. I am My Own Foundation, review of O. A. Westad, review of David Macey, Frantz Fanon: A Life, Granta. 23.20.

Werki, Alice. (2OO2.). "Preface. Fanon, Frantz. Les Damnes de la terre. Paris: Editions Maspero poche. 
Westad, O. A. (2008). in London review of Books, Vol. 30 No. 2, January 24, 2008. "The Project', review of Vijay Prashad, The Darker Nations: A People's History of the Third World." London Review of Books 30.2.

Zahar, R. (1974). Colonialism and Alienation: Political thoughts of Franz. Fanon. Benin City: Ethiope Publishing Company. 